\title{
PENGARUH MOTIVASI BELAJAR DAN KEMAMPUAN NUMERIK TERHADAP PRESTASI BELAJAR AKUNTANSI
}

\author{
Dian Novita \\ Program Studi Informatika, Universitas Indraprasta PGRI \\ Email: dyan.novita21@gmail.com
}

\begin{abstract}
Abstrak
Tujuan dari penelitian ini adalah untuk mengetahui Pengaruh Motivasi Belajar dan Kemampuan Numerik secara bersama-sama Terhadap Prestasi Belajar Akuntansi di SMA Negeri Jakarta Pusat. Jika memang ada pengaruh yang positif dan signifikan maka seberapa kuat pengaruh motivasi belajar dan kemampuan numerik terhadap prestasi Akuntansi. Metode penelitian adalah survei dengan teknik analisis korelasi dan regresi untuk mengetahui pengaruh antar masing-masing variabel, Adapun sampel yang dijadikan objek penelitian adalah siswa yang terkumpul kemudian dianalisis deskriptif statistiknya dan uji persyaratan analisis datanya sebelum dilakukan pengujian hipotesis. Sedangkan data sekunder diperoleh dari dokumentasi sekolah yaitu nilai Ulangan Akhir Semester (UAS). Dari hasil analisis data dan pengujian hipotesis diperoleh simpulan bahwa: (1) Terdapat pengaruh yang signifikan Motivasi belajar dan kemampuan numerik secara bersama-sama terhadap prestasi belajar Akuntansi siswa SMA Negeri Jakarta Pusat. Hal ini dibuktikan dengan nilai sig. $0,000<0,05$ dan $\mathrm{F}$ hitung $=93,792$ (2) Terdapat pengaruh yang signifikan Motivasi belajar terhadap prestasi belajar Akuntansi siswa SMA Negari Jakarta Pusat. Hal ini dibuktikan dengan nilai sig. $0,010<0,05$ dan t hitung $=2,673$. (3) Terdapat pengaruh yang signifikan kemampuan numerik terhadap prestasi belajar Akuntansi siswa SMA Negeri Jakarta Pusat. Hal ini dibuktikan dengan nilai sig. 0,000 < 0,05 dan t hitung = 4,929.
\end{abstract}

Kata Kunci : Motivasi Belajar, Kemampuan Numerik, Prestasi Belajar, Akuntansi

\begin{abstract}
This research aims to show the joint effects of Learning Motivation and Numerical Skill on accounting learning achievement of students of SMA Negeri Jakarta Pusat. If there are positive and significant effects, it can be identified how strong are the effects of learning motivation and numerical skill on accounting learning achievement. The method of the research is a survey with correlation and regression analysis techniques to know the effect of each variable. The sample of the research is students. The statistical description of collected samples are then analyzed and data of requirement test are analyzed before conducting hypothesis test. The secondary data are obtained from school documents, which are scores of Final Test (UAS). From the data analysis and hypothesis test, it can be concluded that: (1) There are jointly significant effects of Learning Motivation and numerical skill on accounting learning achievement of students of SMA Negeri Jakarta Pusat, as shown by the value of sig. $0.000<0.05$ and $F_{\text {Observed }}=93,792$ (2) there is a significant effect of Learning Motivation on accounting learning achievement of students of SMA Negeri Jakarta Pusat, as proven by the values of sig. $0.010<0.05$ and $t_{\text {observed }}=2.673$. (3) There is a significant effect of numerical skill on accounting learning achievement of students of SMA Negeri Jakarta Pusat, as seen by the value of sig. $0.000<0.05$ and $t$ observed $=4.929$.
\end{abstract}

Keywords : Learning Motivation, Numerical Skill, Learning Achivement, Accounting

\section{Pendahuluan}

Pendidikan adalah salah satu usaha yang bersifat sadar tujuan yang dengan sistematis terarah pada perubahan tingkah laku menuju ke kedewasaan anak didik. Pendidikan juga merupakan induk semang kebudayaan, untuk itu pendidikan sangat penting dalam pembangunan bangsa, maka sepantasnya pendiikan mendapatkan suatu perhatian yang cukup dari semua pihak agar tujuan pendidikan dapat tercapai. Dari sekian banyaknya mata pelajaran yang ada, pelajaran akuntansi merupakan salah satu pelajaran yang kurang disukai oleh siswa SMK ataupun 
siswa SLTA (IPS). Sebagian besar siswa memandang pelajaran akuntansi sebagai pelajaran yang menakutkan, entah dilihat dari sudut pandang pengajarnya (dalam hal ini gurunya, karena biasanya pelajaran akuntansi itu identik dengan guru- guru yang galak, kurang ramah, sulit untuk memberikan nilai bagus dan sebagaimya). Ataupun dilihat dari sudut pandang pelajarannya yang selalu menuntut siswa untuk lebih banyak berpikir, harus teliti, dan rumit, serta memecahkan soal-soal yang jawabannya berhubungan dengan angka-angka yang sudah pasti adanya. Kemungkinan para siswa merasa kurang mengerti, kurang percaya diri, dan kurang fokus. Dapat diambil kesimpulan bahwa para siswa kurang menyukai pelajaran akuntansi. Hal itu diperparah dengan kondisi penjurusan yang ada di tingkat SMA. Setelah siswa naik ke kelas XI siswa dituntut untuk menentukan pilihan penjurusan IPA atau IPS. Jurusan IPA identik dengan mata pelajaran yang berbau numeric, sedangkan IPS adalah penjurusan yang identik dengan mata pelajaran social. Ada tiga kelompok siswa yang menghuni jurusan IPS yaitu: pertama siswa yang memanng benar-benar menyukai IPS, kedua siswa yang ingin ke jurusan IPA tetapi nilainya tidak memenuhi kriteriasehingga terpaaksa ke jurusan IPS, yang ke tiga adalah siswa yang ingin menghindari mata pelajaran yang berbau numeric. Namun ternyata di jurusan IPS pun ada mata pelajaran yang berbau numeric yaitu pelajaran akuntansi. Oleh sebab itu peran guru sangatlah penting dalam proses belajar mengajar, bagaimana cara mengubah image-image negatif tersebut. Upaya apakah yang dapat dilakukan para guru menhadapi hal tersebut, karena bagaimanapun peran guru dalam menyampaikan pembelajaran sangat berpengaruh terhadap seberapa besar motivasi siswa untuk menyukai pelajaran tersebut. Guru yang tampak bersemangat dalam menyampaikan pembelajaran akan memotivasi siswa agar lebih bersemangat lagi dan turut aktif dalam proses pembelajaran. Karena bagaimanapun pembelajaran adalah suatu usaha yang turut melibatkan dan menggunakan pengetahuan yang professional yang dimiliki oleh guru untuk mencapai tujuan pembelajaran yang diharapkan. Dengan kata lain pembelajaran adalah suatu aktivitas yang dengan sengaja untuk memodifikasikan berbagai kondisi yang diarahkan untuk tercapainya tujuan pembelajaran.

Berdasarkan uraian-uraian diatas, maka peneliti tertarik untuk meneliti masalah dengan judul "Pengaruh Motivasi Belajar dan Kemampuan Numerik Terhadap Prestasi Belajar Akuntansi" (Survei pada SMA Negeri di Jakarta Pusat). Dengan latar belakang diatas, maka rumusan masalah penelitian ini adalah "Adakah pengaruh motivasi belajar dan kemampuan numerik dengan prestasi belajar akuntansi". Tujuan yang diharapkan dari dilaksanakannya penelitian ini adalah untuk mengetahui pengaruh motivasi belajar dan kemampuan numeric terhadap prestasi belajar akuntansi di SMA Negeri Jakarta Pusat.

\section{Tinjauan Pustaka}

Banyak sekali, bahkan sudah umum orang menyebut dengan "motif" untuk menunjuk mengapa seseorang melakukan sesuatu. Maka dari itu kita harus mengetahui arti dari motif terlebih dahulu, sebelum mengetahui pengertian dari motivasi.

Kata "motif", diartikan sebagai daya upaya yang mendorong seseorang untuk melakukan sesuatu. Motif dapat dikatakan sebagai daya penggerak dari dalam dan di dalam subjek untuk melakukan aktivitas-aktivitas tertentu demi mencapai sesuatu tujuan. Berawal dari kata "motif" itu, maka motivasi dapat diartikan sebagai daya penggerak yang telah menjadi aktif. Motif menjadi aktif pada saat-saat tertentu, terutama bila kebutuhan untuk mencapai tujuan sangat dirasakan atau mendesak.

Menurut Sardiman (2011) "Motivasi dapat juga dikatakan sebagai serangkaian usaha untuk menyediakan kondisi-kondisi tertentu, sehingga seseorang itu mau dan ingin melakukan sesuatu, dan bila ia tidak suka, maka berusaha untuk meniadakan atau mengelakan perasaan tidak suka tersebut. Jadi motivasi itu dapat dirangkai oleh factor dari luar tetapi motivasi adalah tumbuh di dalam diri seseorang". 
Teori tentang motivasi ini lahir dan awal perkembangannya ada di kalangan para psikolog. Menurut ahli ilmu jiwa, dijelaskan bahwa dalam motivasi itu ada suatu hierarki, maksudnya motivasi itu ada tingkatan-tingkatannya, yakni dari bawah keatas. Maslow ( dalam Sardiman 2011: 93) membagi kebutuhan menjadi lima tingkat, yaitu sebagai berikut :

1) Kebutuhan Fisiologis

Kebutuhan fisiologis berkenaan dengan kebutuhan pokok, seperti pangan, papan, sandang dan perumahan.

2) Kebutuhan akan rasa aman

Kebutuhan akan rasa aman berkenaan dengan keamanan yang bersifat fisik, bebas dari rasa takut dan kecemasan.

3) Kebutuhan sosial

Kebutuhan sosial berkenaan dengan perwujudan berupa diterima oleh orang lain dilingkungan sekitar.

4) Kebutuhan akan penghargaan diri

Kebutuhan akan jati diri yang khas, berkesempatan maju, merasa diikutsertakan, dan pemilikan harga diri.

5) Kebutuhan aktualisasi diri

Kebutuhan yang berkenaan dengan kebutuhan individu untuk menjadi sesuatu yang sesuai dengan kemampuannya.

Belajar merupakan kegiatan sehari-hari bagi siswa sekolah. Kegiatan belajar tersebut ada yang dilakukan di sekolah, di rumah, dan di tempat lain seperti di museum, perpustakaan, kebun binatang sawah atau hutan. Pada diri siswa terdapat kekuatan mental yang menjadi penggerak belajar. Kekuatan belajar tersebut berasal dari berbagai sumber. Misalnya saja, motivasi siswa yang rendah akan menjadi lebih baik setelah siswa memperoleh informasi yang benar, atau juga motivasi belajar dapat menjadi rendah dan dapat diperbaiki kembali. Pada kedua peristiwa tersebut peranan guru untuk memperbaiki motivasi belajar siswa sangat berarti.

Motivasi belajar adalah merupakan faktor psikis yang bersifat non-intelektual. Peranan yang khas adalah dalam hal penumbuhan gairah, merasa senang dan semangat untuk belajar. Siswa yang memiliki motivasi kuat, akan mempunyai banyak energi untuk melakukan kegiatan belajar. Guru sebagai pendidik bertugas memperkuat motivasi belajar selama minimal 9 tahun pada usia wajib belajar. Orang tua dan ulama bertugas memperkuat motivasi belajar sepanjang hayat. Penguatan motivasi belajar yang dilakukan oleh guru dapat dilukiskan dalam bagan. Bagan dibawah ini merupakan ganbaran perilaku belajar yang mengandung motivasi belajar yang dikelola oleh guru dan dihayati oleh siswa.

Kemampuan numerik merupakan kemampuan siswa dalam menangani bilangan dan perhitungan. Kemampuan ini identik dengan kemampuan siswa dalam memecahkan persoalan matematika. Dan kemampuan ini dalam multiple intelligence masuk ke dalam wilayah kecerdasan logis-matematis. Linda Cambbel mengatakan bahwa, "kecerdasan logismatematika merupakan kemampuan dalam menghitung, mengukur, dan mempertimbangkan proposisi dan hipotesis, serta menyelesaikan operasi-operasi matematis" (Cambbel, 2009: 2). Sementara Agus Efendi mengatakan bahwa, "kecerdasan logis-matematis adalah kemampuan dalam memahami hubungan-hubungan humanikal" ( Efendi, 2011: 143).

Dari definisi tersebut terlihat bahwa kecerdasan logis-matematis banyak melibatkan banyak komponen; perhitungan secara matematis, berpikir logis, pemecahan masalah, pertimbangan deduktif dan induktif, dan ketajaman pola-pola dan hubungan-hubungan. Matematika dan 
logika dalam hal ini mempunyai hubungan yang erat meskipun secara sejarah keduanya berbeda. Logika dilibatkan dengan pertanyaan-pertanyaan, sedangkan amatematika dengan abstraksi.

Tes deret angka/huruf dilakukan untuk menguji kecepatan, kekonsistenan, dan keakuratan menjawab soal dalam bentuk bilangan-bilangan atau huruf-huruf, atau kombinasi keduanya. Tes operasi bilangan digunakan untuk mengukur pemahaman konsep-konsep aljabar dan aritmatika secara umum dan berguna dalam pemecahan persoalan dalam kehidupan yang berhubungan dengan konsep-konsep perhitungan. Dengan menggunakan tes di atas maka dapat diketahui tingkat kecerdasan logis-matematis dari setiap siswa.

Dari uraian di atas maka dapat disimpulkan bahwa kemampuan numerik merupakan kemampuan untuk menangani bilangan dan perhitungan, pola dan pemikiran logis. Orang yang cerdas secara matematis sering tertarik dengan bilangan dan pola serta mengingatnya dalam jangka waktu yang lebih lama. Selain itu, juga dapat menjelaskan konsep-konsep secara logis, atau menyimpulkan informasi dengan menggunakan matematika.

Proses belajar akan menghasilkan hasil belajar namun harus juga diingat meskipun tujuan pembelajaran itu dirumuskan secara jelas dan baik, belum tentu hasil pengajaran yang diperoleh mesti optimal. Karena hasil yang baik itu dipengaruhi oleh komponen-komponen yang lain, yang terutama bagaimana aktivitas siswa sebagai subjek belajar. Suatu proses belajar mengajar dikatakan baik bila proses tersebut dapat membangkitkan kegiatan belajar yang efektif.

Dalam setiap proses belajar mengajar akan selalu menghasilkan hasil belajar. Yang menjadi masalah adalah sampai tingkat manakah prestasi atau hasil belajar yang telah di capai oleh siswa. Keberhasilan tersebut adalah hasil penyusunan program belajar mengajar oleh guru dan motivasi belajar siswa dalam mengikuti proses belajar mengajar.

Menurut para ahli ekonomi, akuntansi ada sejak manusia mengenal uang sebagai alat pembayaran yang sah. Pencatatan keluar masuknya uang, timbulnya hutang-piutang serta transaksi-transaksi lainnya dilakukan orang mula-mula di atas lempengan tanah liat, yang kemudian berkembang dengan menggunakan lontar.

Teori dan praktek akuntansi semakin berkembang pada abad ke 20 sejalan dengan perkembangan teknologi, seperti program-program akuntansi komputer yang semakin banyak beredar dipasaran pada saat ini. Dalam Kamus Bahasa Indonesia Akuntansi berasal dari kata asing accounting yang artinya bila diterjemahkan ke dalam bahasa indonesia adalah menghitung atau mempertanggung jawabkan.

Fungsi utama akuntansi adalah sebagai informasi keuangan suatu organisasi. Dari laporan akuntansi kita bisa melihat posisi keuangan suatu organisasi beserta perubahan yang terjadi di dalamnya. Akuntansi dibuat secara kualitatif dengan satuan ukuran uang. Informasi mengenai keuangan sangat dibutuhkan khususnya oleh pihak manajer/manajemen untuk membantu membuat keputusan suatu organisasi.

\section{Metodologi Penelitian}

Tempat penelitian dilakukan di SMAN 1 Jakarta Pusat, SMAN 4 Jakarta Pusat, di Provinsi DKI Jakarta. Masing-masing sekolah terdapat 5 kelas program penjurusan IPS di kelas XI dan XII dengan masing-masing kelas berjumlah 36 siswa. Sedangkan Penelitian ini dilaksanakan kurang lebih 4 bulan yaitu terhitung bulan Maret 2016 sampai dengan bulan Juni 2016. Populasi dalam penelitian ini adalah \pm 720 siswa kelas XI dan XII. Untuk 
menentukan jumlah sample dari jumlah populasi diatas, penulis menggunakan rumus yang dikembangkan oleh Isaac dan Michael (Sugiyono, 2007: 79) sebagai berikut :

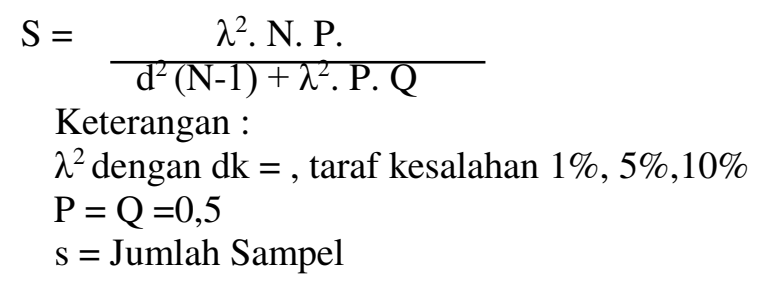

Maka peneliti menetapkan sampel sebanyak 60 responden. Untuk mengumpulkan data yang akan diperoleh dan dianalisis digunakan instrument penelitian. Sesuai dengan metode yang digunakan, instrument untuk penelitian ini berupa angket yang ditujukan kepada siswa-siswa di SMA Negeri Jakarta Pusat.Skala yang digunakan peneliti, yaitu skala Likert yang merupakan jenis skala yang digunakan untuk mengukur variable penelitian. Penelitian ini meneliti 3 variabel, yaitu motivasi belajar (variabel $\mathrm{X}_{1}$ ), kemampuan numerik (variable $\mathrm{X}_{2}$ ) dan prestasi belajar akuntansi (variable $\mathrm{Y}$ ).

Teknik analisis data dalam penelitian ini dilakukan sebagai berikut:

1. Uji Persyaratan Analisis Data

a. Uji Normalitas

Uji normalitas dilakukan untuk mengetahui apakah data penelitian berdistribusi normal atau tidak. Hal ini akan berpengaruh pada proses lanjutan analisis statistik, jika data berdistribusi normal, maka analisis dilanjutkan menggunakan statistik parametrik, sedangkan jika data tidak berdistribusi normal, maka analisis dilanjutkan menggunakan statistik non parametrik.

b. Uji Linieritas Pengujian linieritas garis regresi dalam penelitian ini digunakan Uji F.

c. Uji Multikolinieritas Multikolinieritas adalah penyimpangan model regresi yang disebabkan karena adanya korelasi diantara variabel-variabel bebasnya. Pada model analisis korelasi regresi harus dihindari adanya multikolinieritas.

2. Uji Hipotesis

a. Analisis Korelasi

Hasil perhitungan koefisien korelasi ganda bisa dilihat dari output program SPSS melalui analisis regresi yakni pada tabel Model Summary ${ }^{\mathrm{b}}$.

b. Analisis Regresi

1) Perhitungan Persamaan Garis Regresi

Hasil perhitungan garis regresi bisa dilihat dari output program SPSS melalui analisis regresi yakni pada tabel Coefficients ${ }^{\mathrm{a}}$.

2) Pengujian Signifikansi Regresi

Signifikansi regresi ganda, bisa dilihat dari output program SPSS melalui analisis regresi yakni pada tabel ANOVA $^{\mathrm{b}}$ kolom F atau Sig.

3. Pembahasan Hasil Penelitian

Hasil dan Pembahasan

Uji persyaratan analisis data normalitas

\author{
Tabel 2. Hasil Uji Normalitas Data \\ One-Sample Kolmogorov-Smirnov Test
}




\begin{tabular}{|c|c|c|c|c|}
\hline & & $\begin{array}{c}\text { Motivasi } \\
\text { Belajar }\end{array}$ & $\begin{array}{l}\text { Kemampuan } \\
\text { Numerik }\end{array}$ & $\begin{array}{c}\text { Prestasi } \\
\text { Belajar } \\
\text { Akuntansi }\end{array}$ \\
\hline \multicolumn{2}{|c|}{$\mathrm{N}$} & 60 & 60 & 60 \\
\hline \multirow{2}{*}{$\begin{array}{l}\text { Normal } \\
\text { Parameters }{ }^{a, b}\end{array}$} & Mean & 54,60 & 81,90 & 82,82 \\
\hline & $\begin{array}{c}\text { Std. } \\
\text { Deviation }\end{array}$ & 4,777 & 10,074 & 6,885 \\
\hline \multirow{3}{*}{$\begin{array}{l}\text { Most } \\
\text { Extreme } \\
\text { Differences }\end{array}$} & Absolute &, 150 &, 110 &, 162 \\
\hline & Positive &, 150 &, 081 &, 151 \\
\hline & Negative &,- 104 &,- 110 &,- 162 \\
\hline \multicolumn{2}{|c|}{ Kolmogorov-Smirnov Z } & 1,162 &, 855 & 1,252 \\
\hline \multicolumn{2}{|c|}{ Asymp. Sig. (2-tailed) } &, 134 & ,458 &, 087 \\
\hline \multicolumn{5}{|c|}{ a. Test distribution is Normal. } \\
\hline \multicolumn{5}{|c|}{ b. Calculated from data. } \\
\hline
\end{tabular}

Dari Tabel 2 dapat diketahui bahwa nilai signifikasi untuk Motivasi Belajar sebesar 0, 134 > 0,05 berarti data berdistribusi normal, nilai signifikasi Kemampuan Numerik sebesar 0,458 > 0,05 berarti data berdistribusi normal, dan Prestasi Belajar Akuntansi dengan nilai signifikasi sebesar $0,087>0,05$ berarti data berdistribusi normal.

Uji linearitas prestasi belajar akuntasi atas motivasi belajar

Tabel 3. Uji Linearitas $Y$ atas $X 1$ ANOVA Table

\begin{tabular}{cccccccc}
\hline & & $\begin{array}{c}\text { Sum of } \\
\text { Squares }\end{array}$ & Df & $\begin{array}{c}\text { Mean } \\
\text { Square }\end{array}$ & F & Sig. \\
\hline & & (Combined) & 2145,833 & 18 & 119,213 & 7,506 &, 000 \\
$\begin{array}{c}\text { Prestasi } \\
\text { Belajar } \\
\text { Akuntansi } \\
*\end{array}$ & Between & Linearity & 1867,296 & 1 & 1867,296 & 117,575 &, 000 \\
$\begin{array}{c}\text { Motivasi } \\
\text { Belajar }\end{array}$ & $\begin{array}{c}\text { Deviation } \\
\text { from } \\
\text { Linearity }\end{array}$ & 278,537 & 17 & 16,385 & 1,032 &, 447 \\
& Within Groups & 651,150 & 41 & 15,882 & & \\
\hline
\end{tabular}

Dari data pada tabel 3 diperoleh nilai sig $=0,447>0,05$ dapat disimpulkan Prestasi Belajar Akuntansi (Y) atas Motivasi Belajar $\left(\mathrm{X}_{1}\right)$ berpola linear.

Uji linearitas prestasi belajar akuntasi atas kemampuan numerik

Tabel 4. Uji Linearitas $\mathrm{Y}$ atas $\mathrm{X} 2$ ANOVA Table

\begin{tabular}{|c|c|c|c|c|c|c|c|}
\hline & & & $\begin{array}{l}\text { Sum of } \\
\text { Squares }\end{array}$ & $\mathrm{df}$ & $\begin{array}{l}\text { Mean } \\
\text { Square }\end{array}$ & $\mathrm{F}$ & Sig. \\
\hline \multirow{6}{*}{$\begin{array}{c}\text { Prestasi } \\
\text { Belajar } \\
\text { Akuntansi * } \\
\text { Kemempuan } \\
\text { Numerik }\end{array}$} & \multirow{4}{*}{$\begin{array}{c}\text { Between } \\
\text { Groups }\end{array}$} & (Combined) & 2220,787 & 12 & 185,066 & 15,096 &, 000 \\
\hline & & Linearity & 2063,420 & 1 & 2063,420 & 168,312 &, 000 \\
\hline & & $\begin{array}{l}\text { Deviation } \\
\text { from }\end{array}$ & 157367 & 11 & 14306 & 1167 & 335 \\
\hline & & Linearity & & & & & \\
\hline & \multirow{2}{*}{\multicolumn{2}{|c|}{$\begin{array}{c}\text { Within Groups } \\
\text { Total }\end{array}$}} & 576,196 & 47 & 12,259 & & \\
\hline & & & 2796,983 & 59 & & & \\
\hline
\end{tabular}


Dari data pada Tabel 4 diperoleh nilai sig $=0,335>0,05$ dapat disimpulkan Prestasi Belajar Akuntansi (Y) atas Motivasi Belajar $\left(\mathrm{X}_{1}\right)$ berpola linear.

Uji multikolinieritas

Tabel 5. Uji Multikolinearitas Coefficients $^{\mathrm{a}}$

\begin{tabular}{|c|c|c|c|c|c|c|}
\hline & \multirow{2}{*}{\multicolumn{2}{|c|}{ Model }} & \multicolumn{2}{|c|}{$\begin{array}{l}\text { Unstandardize } \\
\text { d Coefficients }\end{array}$} & \multicolumn{2}{|c|}{ Collinearity Statistics } \\
\hline & & & B & $\begin{array}{l}\text { Std. } \\
\text { Error }\end{array}$ & Tolerance & VIF \\
\hline \multirow{3}{*}{1} & & (Constant) & 24,704 & 5,205 & & \\
\hline & & $\begin{array}{l}\text { Motivasi } \\
\text { Belajar }\end{array}$ & ,460 & , 172 & ,286 & 3,493 \\
\hline & a. Depe & $\begin{array}{c}\text { Kemempuan } \\
\text { Numerik } \\
\text { dent Variable: }\end{array}$ & $\begin{array}{c}\text {,403 } \\
\text { Prestasi } \mathrm{F}\end{array}$ & lajar Al & $\begin{array}{r}, 286 \\
\text { untansi }\end{array}$ & 3,493 \\
\hline
\end{tabular}

Dari Tabel 5 diperoleh nilai tolerance $0,286>0,1$ dan VIF 3,494 < 10 sehingga tidak terjadi multikolinearitas.

Pengujian hipotesis

Tabel 6. Hasil Perhitungan Pengujian Koefisien Regresi Ganda

\begin{tabular}{ccccc}
\hline \multirow{2}{*}{ Model } & $\mathrm{R}$ & $\mathrm{R}$ Square & $\begin{array}{r}\text { Model Summary } \\
\text { Adjusted } \\
\text { R Square }\end{array}$ & $\begin{array}{c}\text { Std. Error of the } \\
\text { Estimate }\end{array}$ \\
\hline 1 &, $876^{\mathrm{a}}$ &, 767 &, 759 & 3,382 \\
a. Predictors: (Constant), Kemempuan Numerik, Motivasi Belajar & \\
\hline
\end{tabular}

Tabel 7. Hasil Perhitungan Pengujian Pengaruh Bersama

\begin{tabular}{|c|c|c|c|c|c|c|}
\hline \multicolumn{7}{|c|}{ ANOVA $^{a}$} \\
\hline \multicolumn{2}{|l|}{ Model } & $\begin{array}{l}\text { Sum of } \\
\text { Squares }\end{array}$ & df & $\begin{array}{c}\text { Mean } \\
\text { Square }\end{array}$ & $\mathrm{F}$ & Sig. \\
\hline \multirow[b]{2}{*}{1} & Regression & 2145,151 & 2 & 1072,575 & 93,792 &, $000^{\mathrm{b}}$ \\
\hline & Residual & $\begin{array}{c}651,832 \\
2796983\end{array}$ & $\begin{array}{l}57 \\
59\end{array}$ & 11,436 & & \\
\hline \multicolumn{7}{|c|}{$\begin{array}{l}\text { a. Dependent Variable: Prestasi Belajar Akuntansi } \\
\text { b. Predictors: (Constant), Kemampuan Numerik, M }\end{array}$} \\
\hline
\end{tabular}

Tabel 8. Hasil Perhitungan uji Hipotesis Parsial

\begin{tabular}{|c|c|c|c|c|c|c|}
\hline \multirow{2}{*}{\multicolumn{2}{|c|}{ Model }} & \multicolumn{2}{|c|}{$\begin{array}{l}\text { Coefficients }^{\mathbf{a}} \\
\text { Unstandardized } \\
\text { Coefficients }\end{array}$} & \multirow{2}{*}{$\begin{array}{c}\text { Standardized } \\
\text { Coefficients } \\
\text { Beta } \\
\end{array}$} & \multirow[t]{2}{*}{$\mathrm{T}$} & \multirow[t]{2}{*}{ Sig. } \\
\hline & & B & Std. Error & & & \\
\hline \multirow[b]{3}{*}{ 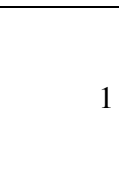 } & (Constant) & 24,704 & 5,205 & & 4,747 & ,000 \\
\hline & $\begin{array}{l}\text { Motivasi } \\
\text { Belajar }\end{array}$ & ,460 &, 172 & ,319 & 2,673 &, 010 \\
\hline & $\begin{array}{c}\text { Kemampuan } \\
\text { Numerik } \\
\text { tt Variable: Prestasi }\end{array}$ & $\begin{array}{l}, 403 \\
\text { lajar Akı }\end{array}$ & $\begin{array}{l}, 082 \\
\text { ansi }\end{array}$ & ,589 & 4,929 &, 000 \\
\hline
\end{tabular}

Dari tabel 6 di atas terlihat bahwa koefisien korelasi ganda pengaruh variabel bebas motivasi belajar $\left(\mathrm{X}_{1}\right)$ dan kemampuan numerik $\left(\mathrm{X}_{2}\right)$ secara bersama-sama terhadap prestasi belajar Akuntansi (Y) adalah sebesar 0,876. Sementara itu, nilai koefisien determinasinya adalah sebesar 0,767 (76,7\%). Berdasarkan hal tersebut maka motivasi belajar dan kemampuan 
numerik memberikan pengaruh tinggi terhadap prestasi belajar akuntansi siswa. Besarnya pengaruh kontribusi kedua variable tersebut terhadap prestasi belajar akuntansi adalah 76,7\% sedangkan sisanya 23,3\% dipengaruhi oleh faktor lain.

Sedangkan untuk pengujian hipotesis melalui analisis regresi diperoleh hasil perhitungan terlihat pada Tabel 7 dan Tabel 8. Dari Tabel 8 diperoleh persamaan garis regresi yang merepresentasikan pengaruh variabel $\mathrm{X}_{1}$ dan $\mathrm{X}_{2}$ terdahap variabel $\mathrm{Y}$, yaitu $\hat{Y}=24,704+$ $0,460 X_{1}+0,403 X_{2}$. Sedangkan pengujian signifikansi garis regresi tersebut adalah dengan memperhatikan hasil perhitungan yang ada pada Tabel 7. Menurut ketentuan yang ada, kriteria signifikansi regresi tersebut adalah "jika $\mathbf{S i g}<0,05$ maka $\mathrm{H}_{0}$ ditolak" atau "jika $\mathbf{F}_{\text {hitung }}>\mathbf{F}_{\text {tabel }}$ maka $\mathrm{H}_{0}$ ditolak", yang berarti bahwa koefisien regresi tersebut signifikan.

Dengan kata lain terdapat pengaruh yang signifikan variabel bebas $X_{1}$ dan $X_{2}$ terhadap variabel terikat Y. Nilai Sig adalah bilangan yang tertera pada kolom Sig dalam Tabel 7 Nilai $\mathbf{F}_{\text {hitung }}$ adalah bilangan yang tertera pada kolom $\mathbf{F}$ dalam Tabel 7. Sedangkan nilai $\mathbf{F}_{\text {tabel }}$ adalah nilai tabel distribusi $\mathbf{F}$ untuk taraf nyata 5\% dengan derajat pembilang $(\mathrm{k})=2$ dan derajat penyebut $(\mathrm{n}-\mathrm{k}-1)=60-2-1=57$ dimana $\mathrm{n}$ adalah banyaknya responden, dan $\mathrm{k}$ adalah banyaknya variabel bebas.

Dari Tabel 7 terlihat bahwa nilai Sig $=0,000<0,05$ dan $\mathbf{F}_{\text {hitung }}=93,792$, maka $\mathrm{H}_{0}$ di tolak yang berarti bahwa koefisien regresi tersebut signifikan. Dengan kata lain bahwa terdapat pengaruh yang signifikan variabel bebas motivasi belajar $\left(\mathrm{X}_{1}\right)$ dan kemampuan numerik $\left(\mathrm{X}_{2}\right)$ secara bersama-sama terhadap prestasi belajar Akuntansi (Y).

Dari Tabel 8 terlihat bahwa nilai $\mathbf{S i g}=0,010<0,05$ dan $\mathbf{t}_{\text {hitung }}=2,673$, maka $\mathrm{H}_{0}$ ditolak yang berarti terdapat pengaruh yang signifikan variabel bebas $\mathrm{X}_{1}$ (motivasi belajar) terhadap variabel terikat Y (prestasi belajar akuntansi).

Dari hasil pengujian korelasi, pengujian regresi maupun dengan melihat model garis tersebut maka bisa disimpulkan bahwa terdapat pengaruh yang signifikan variabel bebas $\mathrm{X}_{1}$ (motivasi belajar) terhadap variabel terikat Y (prestasi belajar akuntansi).

Besarnya kontribusi Motivasi Belajar terhadap Prestasi Belajar Akuntansi adalah : KD = $0,319^{2}$ X $100 \%=10,17 \%$. Hal ini menunjukan bahwa besarnya pengaruh Motivasi Belajar terhadap Prestasi Belajar Akuntansi sebesar 10,17\%.

Dari Tabel 8 terlihat bahwa nilai $\operatorname{Sig}=0,000<0,05$ dan $\mathbf{t}_{\text {hitung }}=4,929$, maka $\mathrm{H}_{0}$ ditolak yang berarti terdapat pengaruh yang signifikan variabel bebas $\mathrm{X}_{2}$ (kemampuan numerik) terhadap variabel terikat Y (prestasi belajar akuntansi). Dari hasil pengujian korelasi, pengujian regresi maupun dengan melihat model garis tersebut maka bisa disimpulkan bahwa terdapat pengaruh yang signifikan variabel bebas $\mathrm{X}_{2}$ (kemampuan numerik) terhadap variabel terikat Y (prestasi belajar akuntansi).

Besarnya kontribusi Kemampuan Numerik terhadap Prestasi Belajar Akuntansi adalah : KD $=0,589^{2} \mathrm{X} 100 \%=34,69 \%$. Hal ini menunjukan bahwa besarnya pengaruh Kemampuan Numerik terhadap Prestasi Belajar Akuntansi sebesar 34,69 \%.

Hasil penelitian di atas menyimpulkan bahwa Motivasi Belajar telah memberikan pengaruh positif terhadap peningkatan Prestasi Belajar Akuntansi. Hal ini mengandung arti bahwa Motivasi Belajar memberikan pengaruh yang cukup signifikan terhadap peningkatan Prestasi Belajar Akuntansi.

Dari deskripsi data setelah dilakukan analisis korelasi diperoleh koefisien korelasi sebesar 0,876. Sementara itu, nilai koefisien determinasinya adalah sebesar 0,767 (76,7\%). .Dari 
perhitungan tersebut di peroleh bahwa koefisien korelasi tersebut signifikan, dengan kata lain bahwa terdapat pengaruh yang signifikan variabel bebas motivasi belajar $\left(\mathrm{X}_{1}\right)$ dan kemampuan numerik $\left(\mathrm{X}_{2}\right)$ secara bersama-sama terhadap prestasi belajar akuntansi $(\mathrm{Y})$.

Sedangkan dari analisis regresi diperoleh persamaan garis regresi yang merepresentasikan pengaruh variabel $\mathrm{X}_{1}$ dan $\mathrm{X}_{2}$ terhadap variabel $\mathrm{Y}$, yaitu $\widehat{\boldsymbol{Y}}=24,704+0,460 \mathrm{X}_{1}+0,403 \mathrm{X}_{2}$. Nilai konstanta $=24,704$ menunjukkan bahwa dengan motivasi belajar dan kemampuan numerik paling rendah sulit bagi siswa untuk meraih prestasi belajar akuntansi, sedangkan nilai koefisien regresi sebesar 0.460 dan 0.403 menunjukkan bahwa terdapat pengaruh positif variabel bebas $\mathrm{X}_{1}$ (motivasi belajar) dan $\mathrm{X}_{2}$ (kemampuan numerik ) secara bersama-sama terhadap variabel terikat $\mathrm{Y}$ (prestasi belajar akuntansi). Setiap ada kenaikan satu nilai pada motivasi belajar maka akan terdapat kenaikan prestasi belajar akuntansi sebesar 0,460 dan setiap ada kenaikan satu nilai kemampuan numerik maka akan terdapat kenaikan prestasi belajar akuntansi sebesar 0,403 .

Motivasi Belajar merupakan salah satu faktor penting yang sangat berpengaruh terhadap prestasi belajar siswa. Oleh karena itu perlu ditumbuhkan dalam kegiatan belajar. Orang yang yang memiliki kemampuan numerik tinggi biasanya menikmati berhitung dan dengan cepat belajar menambah, mengurangi, dan membagi serta dapat mengingat bilangan dalam pikiran dengan cukup lama. Kecenderungannya, orang yang memiliki kemampuan numerik dapat menjelaskan konsep-konsep secara logis, atau menyimpulkan informasi menggunakan matematika lebih dapat meningkatkan pemahaman mereka.

Prestasi siswa dalam belajar dipengruhi oleh : 1) faktor internal yang berasal dari dalam diri siswa, antara lain faktor fisiologis dan psikologis, 2) Faktor eksternal yang berasal dari luar siswa antara lain lingkungan, baik lingkungan keluarga, sekolah dan masyarakat. Motivasi Belajar dan Kemampuan Numerik sangat mempengaruhi prestasi belajar.

Dari penelitian di atas dan teori yang ada dapat disimpulkan bahwa Motivasi Belajar telah memberikan pengaruh positif terhadap peningkatan Prestasi Belajar Akuntansi. Dari pengujian hipotesis diperoleh bahwa nilai $\mathrm{Sig}=0,010$ dan $\mathrm{t}_{\text {hitung }}=2,673$ sedangkan $\mathrm{t}_{\text {tabel }}=$ 2,021. Karena nilai Sig $<0,05$ dan $t_{\text {hitung }}>\mathrm{t}_{\text {tabel }}$ maka $\mathrm{H}_{0}$ di tolak yang berarti terdapat pengaruh yang signifikan variabel bebas $\mathrm{X}_{1}$ terhadap variabel terikat $\mathrm{Y}$. Artinya Motivasi Belajar siswa telah memberikan pengaruh yang signifikan terhadap presatasi belajar akuntansi.

Kewajiban orang tua dalam memberikan perhatian terhadap anak yang paling mendasar adalah memberikan kasih sayang kepada anaknya dengan dasar perasaan kasih sayang yang tulus dan lembut, memberikan pendidikan dan keteladanan kepada anaknya sejak kecil hingga dewasa. Dengan demikian akan tumbuh motivasi pada anak untuk terus menggapai prestasi, tak kalah peran guru di sekolah yang juga harus memupuk motivasi belajar siswa untuk menggapai prestasi.

Dengan hasil demikian maka untuk menghasilkan prestasi belajar yang maksimal para pihak yang berkepentingan dalam rangka proses belajar mengajar sudah sepatutnya memperhatikan faktor motivasi siswa dalam belajar agar tujuan proses belajar mengajar dapat tercapai dengan maksimal.

Hasil penelitian di atas menyimpulkan bahwa Kemampuan Numerik telah memberikan pengaruh positif terhadap peningkatan Prestasi Belajar Akuntansi. Dari pengujian hipotesis diperoleh bahwa nilai Sig $=0,000$ dan $t_{\text {hitung }}=4,929$ sedangkan $t_{\text {tabel }}=2,021$. Karena nilai Sig $<0,05$ dan $\mathrm{t}_{\text {hitung }}>\mathrm{t}_{\text {tabel }}$ maka $\mathrm{H}_{0}$ ditolak yang berarti terdapat pengaruh yang signifikan variabel bebas $\mathrm{X}_{2}$ terhadap variabel terikat $\mathrm{Y}$. Hal ini mengandung arti bahwa Kemampuan 
Numerik siswa memberikan pengaruh yang signifikan terhadap peningkatan Prestasi Belajar Akuntansi.

Dengan hasil penelitian di atas kita tahu bahwa walaupun program jurusan IPS adalah penjurusan yang mengarah pada ilmu sosial namun ada mata pelajaran akuntansi yang ternyata hasil prestasi belajarnya dipengaruhi salah satu faktornya adalah kemampuan numerik. Sehingga sudah sepatutnya para pihak yang berkepentingan dalam proses belajar mengajar senantiasa melatih dan meningkatkan kemampuan numerik siswa agar mampu meraih hasil prestasi belajar yang maksimal.

\section{Simpulan dan Saran \\ Simpulan}

Berdasarkan hasil penelitian, hipotesis dan pembahasan hasil penelitian, maka dapat disimpulkan: 1) Terdapat pengaruh yang signifikan Motivasi belajar dan kemampuan numerik secara bersama-sama terhadap prestasi belajar Akuntansi siswa SMA Negeri Jakarta Pusat. Hal ini dibuktikan dengan nilai sig. $0,000<0,05$ dan $\mathrm{F}$ hitung $=93,792.2$ ) Terhadap pengaruh yang signifikan Motivasi belajar terhadap prestasi belajar Akuntansi siswa SMA Negeri Jakarta Pusat. Hal ini dibuktikan dengan nilai sig. $0,010<0,05$ dan t hitung = 2,673. 3) Terdapat pengaruh yang signifikan kemampuan numerik terhadap prestasi belajar Akuntansi siswa SMA Negeri Jakarta Pusat. Hal ini dibuktikan dengan nilai sig. 0,000< 0,05 dan $\mathrm{t}$ hitung $=4,929$.

\section{Saran}

Berdasarkan simpulan tersebut penulis dapat memebrikan saran 1) Bagi guru sebaiknya dalam proses belajar haruslah dapat meningkatkan motivasi siswa baik melalui nasehat ataupun melalui kegiatan-kegaiatan yang dapat membangkitkan gairah siswa dalam belajar. 2). Bagai orang tua selalu berupaya menjadi orang yang dapat dijadikan siswa sebagai motivasi dalam belajar seperti halnya motivasi untuk membanggakan orang tua dan semua keluarga. 3. Keterkaitan dengan guru Matematika kemampuan numerik siswa harus benarbenar dikembangkan dengan maksimal, karena matematika adalah dasara dari banyak sekali ilmu-ilmu yang lain.

\section{Daftar Pustaka}

A.M. Sardiman. (2011). Interaksi dan Motivasi Belajar Mengajar. Jakarta: PT. Raja Grafindo.

Cambbell, Linda dkk. (2009). Metode Praktis Pembelajaran Berbasis Multiple Intelligence. Depok: Intuisi Press.

Efendi, Agus. (2011). Revolusi Kecerdasan Abd 21, Kritik MI, EI, SQ, dan Successful Intelligemce Atas IQ. Bandung: Alfabeta.

Indrawati F. (2015). Pengaruh Kemampuan Numerik dan Cara Belajar Terhadap Prestasi Belajar Matematika. Formatif: Jurnal Ilmiah Pendidikan MIPA. Vol. 3 No. 3.

Sugiyono. (2007). Metode Penelitian Bisnis. Bandung: Penerbit Alfabeta. 